\title{
Environmental Management of Salt Affected Soils and its Effect on Yield and Quality of Summer Forage Grasses in North Sinai
}

\author{
Zeinab M. Abd El-Naby ${ }^{\#}$ Wafaa A. Hafez ${ }^{*}$, \\ S. A. El-Tohamy* and Nabila A. Mohamed \\ Forage Res. Dept., Field Crop Res. Inst. and ${ }^{*}$ Soil, Water \& \\ Environment Res. Inst., Agric. Res. Center, Giza, Egypt.
}
7 WO FIELD experiments were conducted in Galbana village at Sahl El-Tina site., North Sinai Governorate during two summer seasons (2013 and 2014), to evaluate the effect of some soil amendments and simulating plant growth on soil properties, forage productivity and quality by management salinity of soil and plant resistant to salt. Two forage grasses, Pearl millet (Shandaweel-1) and local Sudan grass, were used and designed in complete randomized blocks (RCBD) with three replications.

Results demonstrated that the soil salinity (EC) was decreased after leaching from 17.78 to $13.42 \mathrm{~d} \mathrm{Sm}^{-1}$. Soil EC values of Sudan grass and Pearl millet resulted low decreasing with control, potassium silicate and nano praticles of $\left(\mathrm{CaCO}_{3}\right)$ treatments in the first and the second seasons. Available macro and micronutrients $\left(\mathrm{mg} \mathrm{kg}^{-1}\right)$ were increased in soil and plant tissues by adding the soil amendments and simulating plant growth, whereas potassium silicate and nano particles of $\mathrm{CaCO}_{3}$ treatments gave the lowest values.

Both Sudan grass and pearl millet reported significant differences $(\mathrm{P} \leq 0.05)$ among yield and its components for the first, second cuts and total yield in the first and second growing seasons. In the first season Sudan grass increased in total dry yield percentages more than fresh yield of compost treatment. Potassium silicate, sulphur and nanoparticles of $\mathrm{CaCO}_{3}$ recorded higher total fresh and dry yield in the second season. For the first season nano particles of $\mathrm{CaCO}_{3}$, potassium silicate and composite of compost, gypsum and sulphur increased the total fresh and dry yield of Pearl millet, also in the second season nano particles of $\mathrm{CaCO}_{3}$ treatment reported the higher total fresh and dry yield. Adding of soil amendments and simulating plant growth treatments increased the efficiency of soil and plant potential to moderate salt stress and increase yield and quality per unit area.

Keywords: Soil salinity, Soil amendments, Compost, Sulphur, Gypsum, Potassium silicates, Nano particles of $\mathrm{CaCO}_{3}$; Sudan grass and pearl millet, Yield, Quality.

\# Corresponding author email: Zeina_bree @ yahoo.com 
Two major environmental factors that currently reduce plant productivity are drought and salinity (Serrano et al., 1999). Salinity becomes a concern when an "excessive" amount or concentration of soluble salts occurs in the soil, either naturally or as a result of mismanagement such as poor irrigation practices. Salinity in the soil or irrigation water is a major stress and especially in arid and semi arid regions, can severely limit crop production (Shannon, 1998).

In Egypt, improving salt affected soils is considered as an important part in the agricultural security program. Gypsum is commonly used for the reclamation of saline-sodic and sodic soils (Amezketa et al., 2005). Gypsum and organic matter are used as amendment for sodic soil reclamation and for reducing the harmful effects of high sodium irrigation water in agricultural areas because of its solubility, low-cost, availability and ease of handling (Wong et al., 2009). Studies on the effects of gypsum application on saline-sodic soil reclamation have shown that the soil receiving gypsum at higher rates removes the greatest amount from the soil columns and causes substantial decreases in soil electrical conductivity (EC) and sodium adsorption ration (SAR) (Hamza \& Anderson, 2003).

Addition of organic matter and gypsum to the surface soil will decrease spontaneous dispersion and EC down to the subsoil, compared to the addition of gypsum alone (Vance et al., 1998). Compost is an organic matter resource resulting from exploiting wastes through controlled bioconversion processes. Several studies have shown the benefits of organic amendments in improving physical, chemical and biological properties of soil depending on the amount and composition (Courtney \& Mullen, 2008) of the applied material.

Sulphur is an efficient amendment for improving the physical, chemical and nutritional properties of the soil and for increasing crop yields especially when its application followed by organic manure application. Kandil \& Gad (2010) stated that sulphur addition enhances plant growth parameters, reduces $\mathrm{pH}$ of soil solution and consequently increases the solubility of the fixed minerals and hence its concentration in the root zone. Potassium silicates encourage seedling germination and establishment, salt tolerance and increase seed yield and quality (Abou Baker et al., 2011). Nano-particles of dolomite have been used recently as an alternative to conventional fertilizers for slow release and efficient use by plants (Bilal, 2010).

Sudan grass (Sorghum sudanense (Piper) Stapf.) and Pearl millet (Pennisetum glaucum (L.) R. Br.) are important warm-season cereals in the semi-arid tropical regions of Asia and Africa, primarily grown for grain production and used as a major source of dietary energy. They are warm-zone cereals grown as forage for livestock in regions where high temperature and low rainfall during late summer and early autumn results in feed deficits on pastoral farms. Sorghum, Sudan grass and pearl millet are $\mathrm{C}_{4}$ species with high photosynthetic potential and dry matter production ability. Millets are classified with maize, sorghum, and coix (Job's tears) in the grass sub-family Panicoideae (Yang et al., 2012).

Egypt. J. Agron . 38, No.1 (2016) 
Millets are major food sources for millions of people, especially those who live in hot, dry areas of the world. They are grown mostly in marginal areas under agricultural conditions in which major cereals fail to give substantial yields (Adekunle, 2012). In contrast, millet is the major source of energy and protein for millions of people in Africa. It has been reported that millet has many nutritious and medical functions (Yang et al., 2012). It also has a low consumption of nitrogen (Olanite et al., 2010); is adapted to hot and dry environments (Yan et al., 2012) and high salt tolerance (Saberi, 2013).

Sorghum and pearl millet gave 4.1 t/ha dry matter that was $37 \%$ more than maize (Singh \& Singh, 1995). Vyas \& Rai (1985) compared the green forage yield of maize, sorghum and pearl millet with pearl millet giving $44 \%$ and sorghum 54\% higher yields than maize. Choi et al. (1993) showed that the digestibility of pearl the millet hybrid Chungaecho varied from $63.4 \%$ (one cut) to $57.6 \%$ (four cuts) compared to $57.6 \%$ and $47.3 \%$, for the same treatments of a sorghum-sudan grass hybrid (Rai et al., 2004). Pearl millet has high levels of lipids, as well as high quality and well-balanced proteins (Elyas et al., 2002). The general effect of salinity is the reduction in growth of sorghum grass (Ghoulam et al., 2002).

In view of global climate change, rising temperatures, increasing water shortages, salinity and increased demand for animal products (meat and milk), these summer grasses have recently gained added importance for their forage value. Despite their differences, these crops have wide agro-ecological adaptation, drought tolerance, a wide range of germplasm with varying degrees of photoperiod sensitivity associated with forage yield and permit multi-cut forage production and grazing (Rai et al., 2004).

The current study aimed to: a) Evaluate the effect of some soil amendments on stimulating plant growth on soil properties and b) Improve forage productivity and quality by management of salinity of soil and plant resistance to salt.

\section{Material and Methods}

The present study was carried out during three summer growing seasons from 2012 till 2014, at the private farm at Gilbana Village of Quntra Sharke. Data of the first summer season (2012) was canceled because the low of survival plants. This area is located in the semi arid region of North Sinai Governorate, Egypt and lies in the north-western Mediterranean coast of Sinai, between $32-35^{\circ}$ and $32-45^{\circ} \mathrm{E}$ and 31- $0.0^{\circ}$ and $31-25^{\circ} \mathrm{N}$, (Kaiser, 2009). Gilbana Village soil is a sandy loam in texture. This area is irrigated with El-Salam canal water (Nile water mixed with agriculture drainage water in the proportion 1:1. Some physical and chemical properties of the investigated soil are presented in Table 1.

\section{Soil tillage}

The soil experimental filed was subjected to continuous leaching process by adding water to soil basins until it reaches a height of $15 \mathrm{~cm}$ above the soil surface. Such height of water was kept constant for 3 days. Two weeks after the leaching process, lazar technique was used for leveling the soil surface followed 
by deep sub-soiling, plowing and establishing field drains at a depth of $90-\mathrm{cm}$ at the beginning of each drain followed by establishment of an irrigation canal in the middle part of the experimental area.

TABLE 1. Some Physical and chemical properties of the experimental soil.

\begin{tabular}{|c|c|c|c|c|c|c|c|c|}
\hline \multicolumn{9}{|c|}{ Particles size distribution } \\
\hline $\begin{array}{c}\text { Coarse sand } \\
(\%)\end{array}$ & $\begin{array}{c}\text { Fine sand } \\
(\%)\end{array}$ & Silt $(\%)$ & \multicolumn{2}{|c|}{ Clay $(\%)$} & $\begin{array}{c}\text { Textural } \\
\text { class }\end{array}$ & \multicolumn{2}{|c|}{ O.M.\% } & $\mathrm{CaCO}_{3} \%$ \\
\hline 7.44 & 68.44 & 9.60 & \multicolumn{2}{|c|}{14.52} & Sandy clay & \multicolumn{2}{|c|}{0.41} & 7.85 \\
\hline \multirow{2}{*}{$\mathrm{pH}(1: 2.5)$} & \multirow{2}{*}{$\begin{array}{c}\text { EC } \\
(\mathrm{dS} / \mathrm{m}) \\
\end{array}$} & \multicolumn{4}{|c|}{ Cations $\left(\mathrm{m} \mathrm{molc}^{-1}\right)$} & \multicolumn{3}{|c|}{ Anions $\left(\mathrm{m} \mathrm{molc}^{-1}\right)$} \\
\hline & & $\mathrm{Ca}^{++}$ & $\mathrm{Mg}^{++}$ & $\mathrm{Na}^{+}$ & $\mathrm{K}^{+}$ & $\mathrm{HCO}_{3}^{-}$ & $\mathrm{Cl}^{-}$ & $\mathrm{SO}_{4}^{--}$ \\
\hline \multicolumn{9}{|c|}{ Before leaching } \\
\hline 8.37 & 17.78 & 38.18 & 41.87 & 131 & 2.34 & 1.93 & 130.4 & 81.99 \\
\hline \multicolumn{9}{|c|}{ After leaching } \\
\hline 8.35 & 13.42 & 10.58 & 26.13 & 101 & 2.01 & 1.00 & 100 & 38.72 \\
\hline \multicolumn{3}{|c|}{ Available Macronutrients $(\mathrm{mg} / \mathrm{kg})$} & \multicolumn{6}{|c|}{ Available Micronutrients $(\mathrm{mg} / \mathrm{kg})$} \\
\hline $\mathrm{N}$ & $\mathrm{P}$ & $\mathrm{K}$ & $\mathrm{Fe}$ & & $\mathrm{Mn}$ & $\mathrm{Zn}$ & & $\mathrm{Cu}$ \\
\hline 60 & 3.10 & 168 & 2.13 & & 1.45 & 0.72 & & 0.008 \\
\hline
\end{tabular}

The experiment treatments were (a) Control (untreated), (b) Four soil amendments: sulphur $(\mathrm{S})(1 \mathrm{Mg} / \mathrm{fed})$, gypsum $(\mathrm{G})(2 \mathrm{Mg} /$ fed $)$, compost $(5 \mathrm{Mg}$ / fed) and composite of (compost, gypsum and sulphur) (C, G and S) and (c) Two stimulating plant growth applications, potassium silicate (k silicate) $(2 \mathrm{gm} / \mathrm{L})$ and nano particles of $\mathrm{Ca} \mathrm{CO}_{3}(5 \mathrm{gm} / \mathrm{L})$.

\section{Preparation compost, gypsum and sulphur}

Gypsum, of $97 \%$ purity was sieved to increasing its solubility. Compost was prepared by mixing straw of rice; maze; sesame and faba bean with farm manure. The mature compost was obtained after 3 months of composting and was passed through a sieve of $10-\mathrm{mm}$ in diameter prior to use in this study. The used amounts of compost; gypsum and sulphur (of $99 \%$ purity) were incorporated in soil and ploughed and followed by irrigation. The treatments were lift for 10 days for drying. Compost was added 25 days before forage planting at a rate of 5 ton $\mathrm{fed}^{-1}$. All soil treatments were applied one month before sowing to assure their complete decomposition and soil was irrigated after sowing. Irrigation was carried out to saturation state of the soil. The compost chemical properties are shown in Table 2. The compost analyses were done according to the standard methods described by Brunner \& Wasmer (1978).

TABLE 2. Chemical properties of the used compost.

\begin{tabular}{|c|c|c|c|c|c|c|c|c|c|c|c|}
\hline $\begin{array}{c}\text { Moisture content } \\
\text { \% }\end{array}$ & $\begin{array}{c}\mathbf{E C} \\
\mathbf{d S m} \\
(\mathbf{1 : 1 0})\end{array}$ & $\begin{array}{c}\mathbf{p H} \\
(\mathbf{1 : 1 0})\end{array}$ & $\mathbf{C}$ & $\mathbf{C} / \mathbf{N}$ & $\mathbf{O . M}$ & $\mathbf{N}$ & $\mathbf{P}$ & $\mathbf{K}$ & $\mathbf{F e}$ & $\mathbf{M n}$ & $\mathbf{Z n}$ \\
\hline 20.25 & 2.35 & 7.65 & 29 & $1: 10$ & 50 & 2.87 & 0.73 & 1.57 & 215 & 120 & 94 \\
\hline
\end{tabular}

Egypt. J. Agron . 38, No.1 (2016) 
Preparation of potassium silicate and nano particles of $\mathrm{CaCO}_{3}$

Liquid Potassium silicate $\left(\mathrm{K}_{2} \mathrm{O} 10 \%, \mathrm{SiO}_{2} 25 \%\right)$ was prepared at a rate of $2 \mathrm{ml} / \mathrm{L}$ and Nano particles of $\mathrm{CaCO}_{3}$ at a rate of $5 \mathrm{~g} / \mathrm{L}$. These were sprayed on plants 21 days after sowing and repeated every 21 days.

\section{Field experiments}

Treatments were designed in a completely randomized block (RCBD) with three replicates. The pearl millet cultivar (Shandaweel-1) and local Sudan grass treatments were arranged in plots of size $12 \mathrm{~m}^{2}(3 \times 4 \mathrm{~m})$. The seeds were hand drilled in rows $4 \mathrm{~m}$ in length and $25 \mathrm{~cm}$ apart at the seeding rate of $15 \mathrm{~kg} / \mathrm{fed}$.

Growth characters (plant height, stem diameter, number of tillers, leaf/stem ratio (L/S\%), fresh weight (FW) and dry weight (DW)) per each cut and total fresh and total dry weight over the two cuts were measured. Germination $\%$ was measured after 15 and 30 days from sowing and then the average mean of the two percentages was conducted. Harvest occurred at approximately $100-120 \mathrm{~cm}$ plant height (Miron et al., 2007) of the two harvest times. After weighing, ten plants were randomly sampled from harvested material from each plot/crop to determine the dry matter $\%$ and dissected into leaf and stem components to allow calculation of the yield of each component and the leaf / stem ratio (LIS\%). All samples were dried in a forced air oven at $70^{\circ} \mathrm{C}$ for $72 \mathrm{~h}$. Standing $\%$ was calculated by counting the number of plants in the second cut as a percentage of the number of plants in the first cut.

Nitrogen fertilizer in the form of ammonium sulphate $(20.6 \% \mathrm{~N})$ was divided into three equal doses. The first dose was applied after germination with the first watering and other doses applied after the first and second cuts.

Recommended rate of phosphorus, $15.5 \% \mathrm{P}_{2} \mathrm{O}_{5}(150 \mathrm{~kg} / \mathrm{fed})$ as mono-super phosphate and potassium, $48 \% \mathrm{~K}_{2} \mathrm{O}(50 \mathrm{~kg} / \mathrm{fed})$ as potassium sulphate were applied before sowing. The sowing dates were the $22^{\text {nd }}$ of June in the 2013 season and the $15^{\text {th }}$ of June in the 2014 season. The common agricultural practices of Sudan grass and pearl millet were followed and two cuts were obtained for each season at 65 and 110 days after sowing.

\section{Soil analysis}

A surface soil sample $(0-30 \mathrm{~cm})$ was collected, air- dried, sieved to pass through a $2 \mathrm{~mm}$ sieve and mixed thoroughly. Calcium carbonate, organic matter, total soluble ions and electrical conductivity (EC) were determined in the saturated soil paste extract while the $\mathrm{pH}$ was measured using a $\mathrm{pH}$ meter in soil suspension (1: 2.5) as described by Page et al. (1982). Available nitrogen was measured according to the modified Kjeldahal method by Black (1965). Available phosphorous, potassium and micronutrients ( $\mathrm{Mn}, \mathrm{Fe}$, and $\mathrm{Zn}$ ) were extracted using ammonium bicarbonate (DTPA) as described by Soltanpour (1985) and determined using Inductively Coupued Plasma (ICP) Spectrometry model 400. 


\section{Plant analysis}

At each of the two harvest times, ten plants were sampled randomly from each plot. The shoots were separated, dried at $70{ }^{\circ} \mathrm{C}$ for three days to determine their dry weight. Dry samples were ground and digested using $\mathrm{H}_{2} \mathrm{SO}_{4}$ and $\mathrm{HClO}_{4}$ acid mixture according to the method described by Black (1965). Plant contents of $\mathrm{N}, \mathrm{P}, \mathrm{K}, \mathrm{Fe}, \mathrm{Mn}$ and $\mathrm{Zn}$ were determined in the plant digests using the methods described by Rebbeca (2004).

\section{Statistical analysis}

Data collected were subjected to analysis of variances using the SAS Statistical Software SAS (2004). Differences between means were compared using both LSD and Duncan's test.

\section{Resuts and Discussion}

\section{Effect of studied applications on soil chemical properties}

Soil pH directly affects the life and growth of plants because it affects the availability of all nutrients. Slight differences of soil $\mathrm{pH}$ occurred when different amendments and stimulating plant growth were applied (Fig.1). However, a contrast based comparison of treated vs. control $\mathrm{pH}$ across all treatments indicated a significant reduction in $\mathrm{pH}$ associated with soil amendments. The $\mathrm{pH}$ of the soil decreased on average with the amendments application this decrease ranged from 8.4 to 8.08 for Sudan grass and from 8.4 to 7.95 for pearl millet during the two grown seasons. This behavior may be due to the organic matter (compost) fraction where the negative charged surfaces are increased due to the dissociation of $\mathrm{H}+$ from certain functional groups particularly from carboxylic ($\mathrm{COOH})$ and phenolic $\left(-\mathrm{C}_{6} \mathrm{H}_{4} \mathrm{OH}\right)$ groups. These results are in agreement with Khan et al. (2006); they found that the soil $\mathrm{pH}$ was decreased with gypsum application in from 8.54 to 7.54. Mahmoud (2011) reported relative decreases in soil $\mathrm{pH}$ from the Control which varied from 8.35 to 8.31 and 8.37 to 8.17 averaged over two seasons for gypsum and sulphur treatments, respectively.
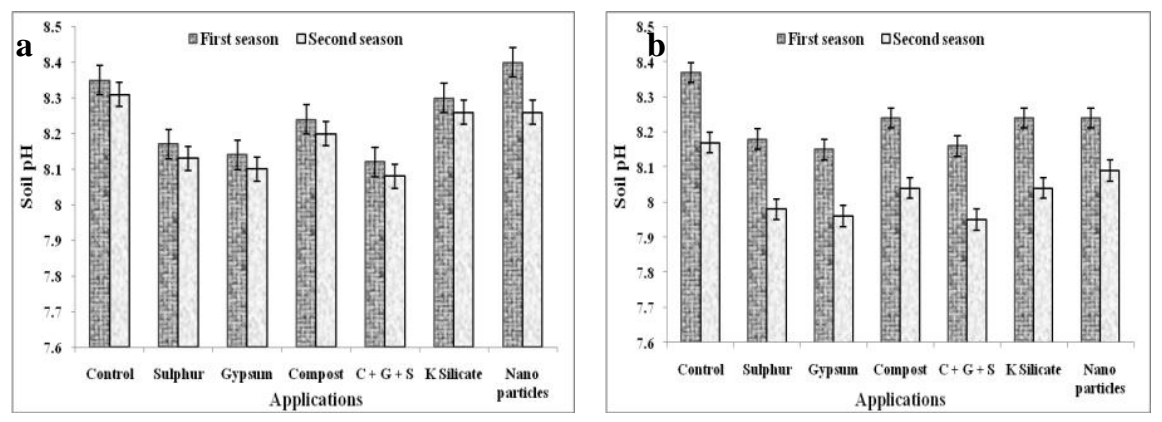

Fig. 1. Soil $\mathrm{pH}$ after plant harvested $( \pm \mathrm{SE})$ for two forage grasses (a) Sudan grass and (b) Pearl millet.

Egypt. J. Agron. 38, No.1 (2016) 
Soil salinity $\left(\mathrm{EC} \mathrm{dSm}{ }^{-1}\right)$ values were decreased from $17.78 \mathrm{dSm}^{-1}$ to $13.42 \mathrm{dSm}^{-1}$ after leaching (Table 1). The effect of different soil amendments application on the soil salinity $\left(\mathrm{EC} \mathrm{dSm}^{-1}\right)$ after harvesting for the two successive growing seasons are presented in Table 3. The soil amendments showed significant reductions on EC for gypsum, compost and composite of ( $\mathrm{C}, \mathrm{G}$ and $\mathrm{S})$ for both seasons. Sudan grass treatments gave EC values ranged from $8.85 \mathrm{dSm}^{-1}$ (Gypsum) to $12.47 \mathrm{dSm}^{-1}$ (control) with an average of $10.16 \mathrm{dSm}^{-1}$ for the $1^{\text {st }}$ season and also ranged from $5.63 \mathrm{dSm}^{-1}$ (composite of $(\mathrm{C}+\mathrm{G}+\mathrm{S})$ ) to $10.68 \mathrm{dSm}^{-1}$ (Control) with an average of $7.91 \mathrm{dSm}^{-1}$ in the $2^{\text {nd }}$ season. Similar decreases of soil $\mathrm{EC} \mathrm{dSm}^{-1}$ were found for pearl millet across treatments (Table 3-b). In the $1^{\text {st }}$ season EC reduction values ranged from $8.62 \%$ (Compost) to $11.97 \%$ (Control) with a mean of $9.66 \%$ across pearl millet treatments. For the $2^{\text {nd }}$ growing season treatments produced similar reductions in soil $\mathrm{Ec} \mathrm{dSm}^{-1}$ which ranged from $5.33 \mathrm{dSm}^{-1}$ (Compost) to $10.38 \mathrm{dSm}^{-1}$ with a mean of $7.61 \mathrm{dSm}^{-1}$.

Figure 2 shows the soil EC $( \pm \mathrm{SE})$ reduction\% of treatments related to the soil EC of control (untreated) of Sudan grass and Pearl millet forage grasses. Soil EC reduction, related to control, ranged from $11.22 \%$ (K silicate) to $37.83 \%$ (gypsum) with an average of $22.08 \%$ across the two seasons. Gypsum and sulphur applications gave the highest EC reduction (29.03 and 26.30\%) in the first growing season while, composite (C, G and $\mathrm{S})$, gypsum and compost applications gave the highest reduction $(47.28,46.63$ and $42.70 \%$, respectively) in the second season. These decreased of soil EC may be due to the improvement in soil porosity and hydraulic conductivity by adding soil amendments, which resulted from enhancement the leaching of salts. These results are in contrary with Hussain et al. (2001); they reported that the slight decrease occurred when different amendments were applied in combination or alone except for use of sulphur or its combination with FYM.

TABLE 3. Soil EC, macro and micronutrients content in soil after harvesting of two treated seasons.

\begin{tabular}{|c|c|c|c|c|c|c|c|c|c|c|c|c|c|c|c|c|}
\hline \multirow{3}{*}{\begin{tabular}{|c|} 
Treatment \\
Season \\
\end{tabular}} & \multirow{2}{*}{\multicolumn{2}{|c|}{$\underset{\left(\mathbf{d S m}^{-1}\right)}{\mathrm{EC}}$}} & \multicolumn{6}{|c|}{ Available macronutrients $\left(\mathrm{mg} \mathrm{kg}^{-1}\right)$} & \multicolumn{8}{|c|}{ Available micronutrients $\left(\mathrm{mg} \mathrm{kg}^{-1}\right)$} \\
\hline & & & \multicolumn{2}{|c|}{$\mathbf{N}$} & \multicolumn{2}{|c|}{$\mathbf{K}$} & \multicolumn{2}{|c|}{$\mathbf{P}$} & \multicolumn{2}{|c|}{ Mn } & \multicolumn{2}{|c|}{\begin{tabular}{|l|}
$\mathbf{Z n}$ \\
\end{tabular}} & \multicolumn{2}{|c|}{$\mathrm{Fe}$} & \multicolumn{2}{|c|}{$\mathbf{C u}$} \\
\hline & $\mathbf{1}^{\text {st }}$ & $2^{\text {nd }}$ & $1^{\text {st }}$ & $2^{\text {nd }}$ & $1^{\text {st }}$ & $2^{\text {nd }}$ & $1^{\text {st }}$ & $2^{\text {nd }}$ & $1^{\text {st }}$ & $2^{\text {nd }}$ & $1^{\text {st }}$ & $2^{\text {nd }}$ & $1^{\text {st }}$ & $2^{\text {nd }}$ & $1^{\text {st }}$ & $2^{\text {nd }}$ \\
\hline & & & & & \multicolumn{12}{|c|}{ a-Sudan grass } \\
\hline Control & 12.47 & 10.68 & 80.0 & 130 & 320 & 570 & 10.89 & 11.14 & 2.81 & 3.06 & 0.66 & 0.91 & 30.75 & 31.0 & 0.13 & 0.38 \\
\hline Sulphur & 9.19 & 7.47 & 160.0 & 170 & 410 & 660 & 11.08 & 13.03 & 3.27 & 3.52 & 1.21 & 1.46 & 31.11 & 31.36 & 0.14 & 0.38 \\
\hline Gypsum & 8.85 & 5.70 & 130.1 & 230 & 410 & 660 & 12.97 & 13.22 & 5.62 & 5.87 & 1.34 & 1.59 & 32.90 & 33.15 & 0.23 & 0.48 \\
\hline Compost & 9.96 & 6.12 & 160.1 & 330 & 410 & 660 & 14.91 & 15.16 & 8.79 & 9.04 & 2.14 & 2.39 & 34.06 & 34.31 & 0.34 & 0.59 \\
\hline $\mathrm{C}+\mathrm{G}+\mathrm{S}$ & 9.80 & 5.63 & 150.0 & 310 & 410 & 660 & 13.76 & 14.01 & 10.29 & 10.54 & 1.68 & 1.92 & 36.32 & 36.41 & 0.28 & 0.53 \\
\hline $\mathrm{K}$ sil & 10.7 & 9.80 & 130.0 & 270 & & 676 & & 13.02 & & 879 & & & & 31.57 & & 39 \\
\hline $\begin{array}{c}\text { Nano } \\
\text { particles }\end{array}$ & 10.12 & 9.96 & 110.1 & 250 & 410 & 660 & 12.78 & 11.33 & 4.28 & 4.53 & 0.67 & 0.92 & 31.32 & 31.50 & 0.13 & 0.38 \\
\hline$n$ & 10.16 & 7.91 & 130 & 260 & 420 & 650 & 12.74 & 12.99 & 23 & 6.48 & 24 & 1.49 & 3 & 32.76 & 0.20 & 0.45 \\
\hline \multirow[t]{2}{*}{$\operatorname{LSD}(0.05)$} & 0.303 & 0.490 & 0.041 & 0.083 & 0.033 & 0.033 & 0.012 & 0.012 & 0.989 & 0.989 & 0.281 & 0.028 & 1.245 & 0.303 & 0.490 & 0.542 \\
\hline & & & & & \multicolumn{12}{|c|}{ b-Pearl millet } \\
\hline Control & 11.97 & 10.38 & 110 & 230 & 320 & 640 & 11.94 & 22.99 & 8.68 & 17.35 & \begin{tabular}{|l|}
0.21 \\
\end{tabular} & \begin{tabular}{|l|}
0.43 \\
\end{tabular} & 24.24 & 26.24 & \begin{tabular}{|l|}
0.13 \\
\end{tabular} & 0.27 \\
\hline Sulphur & 8.35 & 7.17 & 160 & 330 & 410 & 830 & 12.81 & 25.63 & 10.13 & 24.99 & 0.25 & \begin{tabular}{|l|}
0.50 \\
\end{tabular} & 28.58 & 30.58 & \begin{tabular}{|l|}
0.18 \\
\end{tabular} & 0.43 \\
\hline \begin{tabular}{|l|} 
Gypsum \\
\end{tabular} & 9.30 & 5.82 & 160 & 300 & 410 & 830 & 13.37 & 26.75 & 11.21 & 25.15 & 0.25 & \begin{tabular}{|l|}
0.50 \\
\end{tabular} & 30.92 & 32.92 & 0.23 & 0.47 \\
\hline \begin{tabular}{|l|} 
Compost \\
\end{tabular} & 8.62 & 5.33 & 180 & 350 & 560 & 970 & 14.73 & 28.49 & 18.27 & 36.53 & 0.31 & \begin{tabular}{|l|}
0.63 \\
\end{tabular} & 34.86 & 36.86 & 0.34 & 0.67 \\
\hline & 9.46 & 5.40 & 170 & 35 & 49 & 970 & 14.24 & 29.46 & 15.32 & 30.64 & 29 & \begin{tabular}{|l|}
0.59 \\
\end{tabular} & 30.96 & 32.96 & \begin{tabular}{|l|}
0.24 \\
\end{tabular} & 0.49 \\
\hline \begin{tabular}{|l|} 
K silicate \\
\end{tabular} & 9.62 & 9.50 & 130 & 270 & 490 & 1130 & 12.24 & 24.49 & 12.57 & 22.43 & 0.24 & \begin{tabular}{|l|}
0.47 \\
\end{tabular} & 26.74 & 28.74 & 0.21 & 0.37 \\
\hline \begin{tabular}{|c|} 
Nano \\
particles
\end{tabular} & 10.2 & 9.66 & 30 & 250 & 330 & 670 & 12.33 & 24.65 & 12.49 & 20.25 & 0.23 & 0.46 & 25.12 & 27.12 & 0.19 & 0.36 \\
\hline Mean & 9.66 & 7.61 & 150 & 300 & 430 & 950 & 13.09 & 26.06 & 12.67 & 25.33 & 0.26 & \begin{tabular}{|l|}
0.51 \\
\end{tabular} & 28.78 & 30.78 & \begin{tabular}{|l|}
0.22 \\
\end{tabular} & 0.44 \\
\hline$\overline{\mathrm{SD}(0.05}$ & 0.303 & 0.490 & 10000 & 0020 & 0.932 & 0.324 & 0.040 & 0.08 & 0.0865 & 0.173 & 0.02 & 0.04 & 0.5708 & 0.30 & 0.49 & .0631 \\
\hline
\end{tabular}




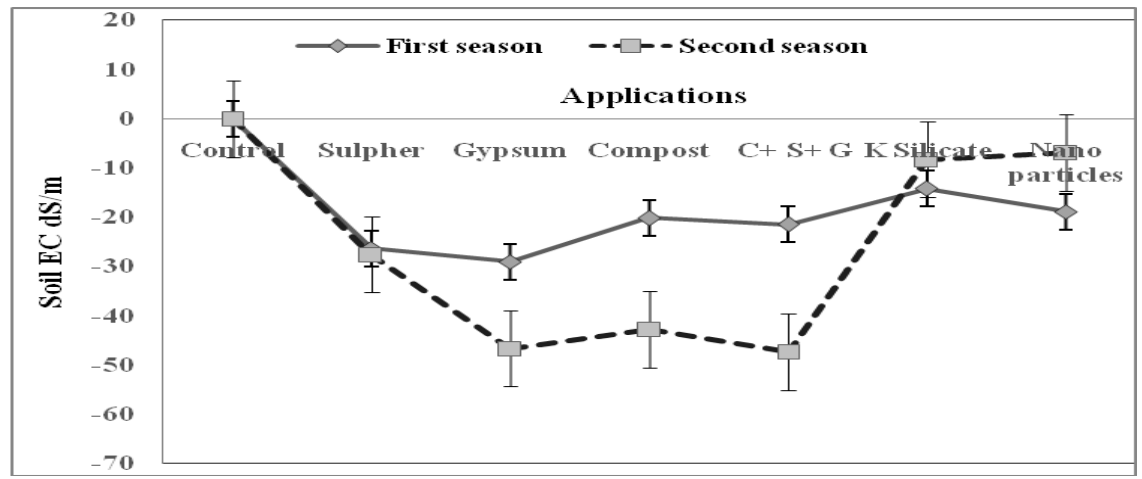

Fig. 2. Soil EC reduction $\%( \pm \mathrm{SE})$ related to control treatment in first and second growing seasons.

Available macronutrients in soil

The presented data in Table 3 show the soil contents of available N, P and K $\left(\mathrm{mg} \mathrm{kg}^{-1}\right)$. Available macronutrients content was increased as a result of salt affected soil treated by the soil amendments. This increasing may be attributed to the effect of different application rate of sulphur, compost, gypsum and composite (C, G and $\mathrm{S}$ ) caused an increasing in the availability of $\mathrm{N}, \mathrm{P}$ and $\mathrm{K}$ in the soil as well as these contents were increased with adding of soil amendment treatments. Compost, sulphur and gypsum applications recorded significantly increasing of available $\mathrm{N}, \mathrm{P}$ and $\mathrm{K}$ soil content in the first and second seasons, respectively. Whereas, both of Potassium silicate and Nano particles treatments gave the lowest value of available $\mathrm{N}, \mathrm{P}$ and $\mathrm{K}$ in the $1^{\text {st }}$ and $2^{\text {nd }}$ seasons. These findings are in agreement with the results obtained by Mahmoud (2011).

In general, the application of gypsum increased the solubility of $\mathrm{N}$ and $\mathrm{K}$, whereas it decreased the solubility of $\mathrm{P}$, whereas $\mathrm{P}$ may be related with soluble $\mathrm{Ca}++$ released from added gypsum found less soluble $\mathrm{P}$ compounds namely Calcium phosphate. The application of compost increased the solubility of all tested nutrients in the study soil. These results are in agreements with El Rashidi et al. (2010), they found that the application of peat improved the solubility of most nutrients in the soil. Sulphur element plays a great role in plant metabolism and supplying it to the soil caused reduction in the soil $\mathrm{pH}$, consequently enhances the solubility and availability of many elements (Lai et al., 2000).

\section{Available micronutrients in soil}

It is evident from data present in Table 3 that increase of soil available microelement contents $(\mathrm{Mn}, \mathrm{Zn}, \mathrm{Fe}$ and $\mathrm{Cu}$ ) were resulted from soil amendment applications. The availability of micronutrients in soil depends on the change of soil $\mathrm{pH}$, resulted from the treatments of the tested soil amendments. Thus it could be concluded that the more pronounced increase in the available $\mathrm{Mn}, \mathrm{Zn}, \mathrm{Fe}$ and $\mathrm{Cu}$ contents as a result of increasing the applied rates of different soil amendments may be attributed to improve soil $\mathrm{pH}$. This finding is in agreement with results obtained by Mahmoud (2011). These increases may be due to the release of organic acids up on decomposition of the applied organic matter Egypt. J. Agron . 38, No.1 (2016) 
because of the organic matter is considered as a source of $\mathrm{Mn}, \mathrm{Zn}$ and Fe. These results are in agreement with Abdel Aal et al. (2003) who found that the application of organic materials caused a substantial increase in $\mathrm{Mn}, \mathrm{Zn}, \mathrm{Fe}$ and $\mathrm{Cu}$ in soil. Sulphure, Compost, Gypsum, Composite $(\mathrm{C}+\mathrm{G}+\mathrm{S})$ caused an increasing in the availability of ( $\mathrm{Mn}, \mathrm{Zn}, \mathrm{Fe}$ and $\mathrm{Cu}$ ) whereas Nano-particles and Potassium silicate improved the plant tolerance to salt stress.

Forage Sudan grass and Pearl millet yield and yield components

Data presented in Table $4(\mathrm{a}, \mathrm{b})$ show the effect of soil amendments application (sulphur, gypsum, compost, composite (C, G and S), k silicate, and nano-particles) on yield and yield component of Sudan grass and Pearl millet plants.

TABLE 4-a. Means of forage yield and yield components for two cuts of Sudan grass in two growing seasons at Sahl El -Tina salt soils.

\begin{tabular}{|c|c|c|c|c|c|c|c|c|c|c|c|c|c|c|c|c|}
\hline \multirow[b]{2}{*}{$\stackrel{n}{\tilde{E}}$} & \multirow[b]{2}{*}{ 氖 } & \multicolumn{6}{|c|}{$1^{\text {st }}$ cut } & \multirow[b]{2}{*}{ 昰 。 } & \multicolumn{6}{|c|}{$2^{\text {st }}$ cut } & \multicolumn{2}{|c|}{ Total } \\
\hline & & 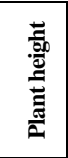 & 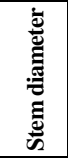 & 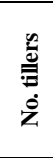 & $\begin{array}{l}5 \\
5 \\
2\end{array}$ & $\frac{\vec{d}}{3}$ & 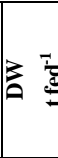 & & 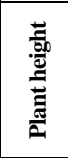 & 矛 & $\begin{array}{l}\text { 递 } \\
\dot{0} \\
\dot{0}\end{array}$ & $\sum_{0}^{\infty}$ & 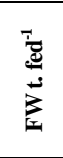 & 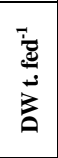 & 3 & 3 \\
\hline \multicolumn{17}{|c|}{ First season } \\
\hline Control & 38.33 & 86.33 & 0.87 & 1.23 & 47.17 & 9.85 & 2.66 & 74.67 & 172.67 & 1.11 & 4.27 & 51.75 & 13.47 & 3.63 & 23.32 & 6.29 \\
\hline Sulphur & 59.00 & 107.33 & 1.07 & 1.75 & 57.00 & 10.40 & 2.81 & 89.33 & 243.33 & 1.13 & 6.17 & 64.58 & 17.00 & 4.59 & 27.40 & 7.43 \\
\hline Gypsum & 53.33 & 104.00 & 0.83 & 2.17 & 3.50 & 9.32 & 2.52 & 81.33 & 222.00 & 1.13 & 5.60 & 67.42 & 14.73 & 3.98 & 24.05 & 6.51 \\
\hline npost & 51.00 & 124.67 & 1.30 & 2.13 & 60.00 & 11.44 & 3.09 & 88.00 & 242.67 & 1.10 & 6.47 & 68.5 & 16.38 & 4.43 & 27.82 & 7.52 \\
\hline $\mathrm{C}+\mathrm{G}+\mathrm{S}$ & 47.67 & 106.67 & 1.20 & 1.93 & 62.17 & 10.69 & 2.91 & 88.33 & 211.00 & 1.03 & 8.37 & 69.17 & 16.59 & 4.48 & 27.28 & 7.39 \\
\hline $\begin{array}{c}\mathrm{K} \\
\text { silicate }\end{array}$ & 56.67 & 146.67 & 1.50 & 2.31 & 64.50 & 11.11 & 2.99 & 82.67 & 227.67 & 1.17 & 8.40 & 67.83 & 17.04 & 4.60 & 28.15 & 7.59 \\
\hline $\begin{array}{c}\text { Nano } \\
\text { particles }\end{array}$ & 1.67 & 0.00 & 1.29 & 2.03 & 64.50 & 10.77 & 2.97 & 93.00 & 216.67 & 1.11 & 7.64 & 70.75 & 24.44 & 60 & 35.21 & 9.57 \\
\hline Mean & 52.52 & 116.52 & 1.17 & 1.93 & 59.12 & 10.51 & 2.85 & 85.33 & 219.43 & 1.11 & 6.71 & 65.71 & 17.09 & 4.62 & 27.6 & 7.47 \\
\hline $\begin{array}{l}\text { L.S.D. } \\
(0.05)\end{array}$ & 16.42 & 27.21 & 0.67 & 0.43 & 8.73 & 3.91 & 1.09 & 22.91 & 51.48 & 0.21 & 3.18 & 14.99 & 6.90 & 1.86 & 4.37 & 1.76 \\
\hline \multicolumn{17}{|c|}{ Second season } \\
\hline Control & 46.67 & 91.33 & 0.73 & 3.39 & 46.33 & 11.10 & 3.33 & 81.53 & 186.33 & 0.97 & 8.33 & 58.00 & 18.07 & 4.88 & 29.17 & 8.21 \\
\hline Sulphur & 63.33 & 109.00 & 1.20 & 4.73 & 59.00 & 22.97 & 6.89 & 89.00 & 213.67 & 1.07 & 17.00 & 67.67 & 30.33 & 8.19 & 53.3 & 15.08 \\
\hline Gypsum & 55.67 & 114.67 & 0.97 & 4.85 & 60.00 & 19.98 & 5.99 & 83.33 & 204.00 & 0.83 & 13.30 & 64.00 & 24.97 & 6.74 & 44.95 & 12.73 \\
\hline Compost & 54.00 & 158.33 & 1.31 & 4.75 & 67.67 & 19.81 & 5.70 & 91.00 & 234.67 & 1.50 & 15.02 & 63.33 & 28.00 & 7.56 & 47.81 & 13.26 \\
\hline $\mathrm{C}+\mathrm{G}+\mathrm{S}$ & 53.33 & 123.33 & 1.23 & 5.66 & 59.67 & 22.32 & 6.74 & 67 & 216.67 & 1.20 & 13.11 & 5.33 & 27.73 & 7.49 & 50.05 & 14.23 \\
\hline $\begin{array}{c}\mathrm{K} \\
\text { silicate }\end{array}$ & 8.99 & 132.33 & 1.22 & 5.21 & 69.33 & 21.27 & 6.38 & 87.67 & 219.00 & 1.30 & 16.67 & 65.33 & 32.11 & 8.67 & 53.38 & 15.05 \\
\hline $\begin{array}{c}\text { Nano } \\
\text { particles }\end{array}$ & 65.33 & 135.00 & 1.27 & 4.45 & 69.35 & 21.34 & 6.40 & 95.67 & 227.33 & 1.29 & 18.56 & 67.67 & 30.67 & 8.28 & 52.01 & 14.68 \\
\hline Mean & 56.76 & 123.43 & 0.85 & 4.72 & 61.62 & 19.83 & 5.92 & 88.02 & 211.67 & 1.165 & 14.75 & 64.62 & 27.41 & 7.40 & 47.24 & 13.32 \\
\hline $\begin{array}{l}\text { L.S.D. } \\
(0.05)\end{array}$ & 15.67 & n.s. & 0.395 & 1.32 & n.s. & 4.696 & 1.41 & 16.42 & 47.20 & n.s. & 11.37 & 2.088 & 4.797 & 1.294 & 7.168 & 2.043 \\
\hline
\end{tabular}

$\mathrm{C}+\mathrm{G}+\mathrm{S}=$ composite of (Compost, Gypsum and Sulphur) and $\mathrm{k}$ silicate= Potassium silicate 
TABLE 4b . Means of forage yield and yield components for two cuts of Pearl millet in two growing seasons at Sahl El-Tina salt soils.

\begin{tabular}{|c|c|c|c|c|c|c|c|c|c|c|c|c|c|c|c|c|}
\hline \multirow[b]{2}{*}{ 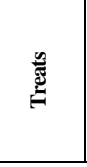 } & \multirow[b]{2}{*}{ 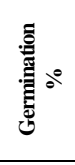 } & \multicolumn{6}{|c|}{$1^{\text {st }}$ cut } & \multirow[b]{2}{*}{ 馬 } & \multicolumn{6}{|c|}{$2^{\text {st }}$ cut } & \multicolumn{2}{|c|}{ Total } \\
\hline & & 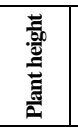 & 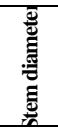 & $\begin{array}{l}\text { 量 } \\
\text { 产 } \\
\dot{0} \\
\dot{z}\end{array}$ & $\sum^{\circ}$ & $\frac{i}{\vec{Z}}$ & 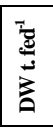 & & 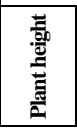 & 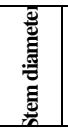 & 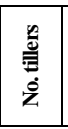 & $\sum^{\circ}$ & 蛋焉 & 要要 & 3 & 3 \\
\hline \multicolumn{17}{|c|}{ First season } \\
\hline Control & 25.33 & 54.33 & 0.33 & 3.54 & 45.00 & 6.93 & 1.58 & 48.33 & 82.67 & 0.43 & 7.73 & 46.65 & 7.33 & 2.16 & 14.26 & 3.74 \\
\hline Sulphur & 42.04 & 100.67 & 0.53 & 6.41 & 58.35 & 12.67 & 4.25 & 66.67 & 89.00 & 0.60 & 9.63 & 63.35 & 13.02 & 4.29 & 25.69 & 8.54 \\
\hline Gypsum & 53.33 & 82.00 & 0.68 & 5.66 & 61.65 & 12.32 & 4.18 & 56.67 & 100.0 & 0.63 & 10.95 & 58.35 & 14.58 & 4.65 & 26.90 & 8.83 \\
\hline Compost & 51.67 & 99.33 & 0.40 & 7.32 & 45.00 & 7.95 & 1.81 & 73.33 & 140.0 & 1.03 & 13.73 & 63.35 & 9.67 & 3.05 & 17.62 & 4.86 \\
\hline $\mathrm{C}+\mathrm{G}+\mathrm{S}$ & 39.33 & 84.33 & 0.73 & 6.97 & 60.00 & 11.00 & 3.82 & 68.33 & 126.67 & 0.63 & 13.67 & 55.00 & 14.94 & 4.44 & 27.32 & 8.97 \\
\hline $\begin{array}{c}\mathrm{K} \\
\text { silicate }\end{array}$ & 49.67 & 120.67 & 0.73 & 7.43 & 63.35 & 13.02 & 4.37 & 80.00 & 106.67 & 0.77 & 12.80 & 59.05 & 16.32 & 5.15 & 27.96 & 8.81 \\
\hline $\begin{array}{c}\text { Nano } \\
\text { particles }\end{array}$ & 53.67 & 105.33 & 0.70 & 7.11 & 63.35 & 13.67 & 4.86 & 80.00 & 166.67 & 0.87 & 10.27 & 68.35 & 16.17 & 5.29 & 29.84 & 10.15 \\
\hline Mean & 45.01 & 92.38 & 0.57 & 6.35 & 56.67 & 11.08 & 3.55 & 67.62 & 115.95 & 0.71 & 11.25 & 59.16 & 13.15 & 4.15 & 24.23 & 7.70 \\
\hline $\begin{array}{l}\text { L.S.D. } \\
(0.05)\end{array}$ & 13.88 & 24.17 & 0.33 & 2.12 & 3.55 & 6.07 & 1.46 & 22.27 & 52.97 & 0.094 & 2.86 & 2.61 & 4.15 & 1.251 & 7.80 & 1.95 \\
\hline \multicolumn{17}{|c|}{ Second season } \\
\hline Control & 26.67 & 83.33 & 0.52 & 2.37 & 37.00 & 8.79 & 2.59 & 62.00 & 91.67 & 0.60 & 7.10 & 43.17 & 6.63 & 2.03 & 15.42 & 4.62 \\
\hline Sulphur & 45.0 & 124.75 & 0.91 & 7.23 & 58.00 & 13.81 & 4.34 & 75.33 & 115.00 & 0.63 & 10.43 & 60.67 & 15.19 & 4.38 & 29.00 & 8.72 \\
\hline Gypsum & 66.67 & 113.67 & 0.93 & 6.43 & 56.00 & 12.78 & 3.83 & 82.67 & 112.67 & 0.80 & 11.77 & 60.67 & 21.77 & 6.07 & 34.55 & 9.90 \\
\hline Compost & 41.67 & 124.67 & 1.13 & 7.53 & 56.00 & 15.13 & 4.74 & 80.67 & 153.33 & 0.67 & 10.60 & 57.67 & 17.54 & 4.52 & 32.67 & 9.26 \\
\hline $\mathrm{C}+\mathrm{G}+\mathrm{S}$ & 63.67 & 94.67 & 1.03 & 5.43 & 47.33 & 11.95 & 4.24 & 77.50 & 137.33 & 1.03 & 10.50 & 58.31 & 21.37 & 5.94 & 33.32 & 10.18 \\
\hline $\begin{array}{c}\mathrm{K} \\
\text { silicate }\end{array}$ & 61.6 & 111.33 & 1.22 & 6.62 & 65.10 & 16.26 & 4.84 & 84.67 & 141.33 & 0.87 & 12.67 & 59.67 & 23.71 & 6.16 & 39.97 & 10.98 \\
\hline $\begin{array}{c}\text { Nano } \\
\text { particles }\end{array}$ & 71.67 & 112.67 & 1.23 & 6.67 & 64.00 & 18.54 & 5.76 & 86.00 & 152.33 & 0.77 & 12.36 & 62.67 & 23.75 & 6.18 & 42.29 & 11.94 \\
\hline Mean & 53.85 & 109.30 & 1.00 & 6.04 & 54.78 & 13.89 & 4.25 & 78.41 & 129.09 & 0.77 & 10.78 & 57.55 & 18.57 & 5.04 & 32.46 & 9.37 \\
\hline $\begin{array}{l}\text { L.S.D. } \\
(0.05)\end{array}$ & 15.34 & 31.24 & 0.45 & 1.92 & 28.26 & 9.28 & 3.15 & 24.85 & 51.80 & 0.34 & 3.00 & 11.42 & 9.04 & 2.47 & 18.32 & 5.62 \\
\hline
\end{tabular}

Sudan grass (Piper) growth attributes

There were significant differences $(\mathrm{P}<0.05)$ among yield and its components for the first, second cuts and total yield in the first and second seasons of forage Sudan grass in salt soil stress (Table 4-a).

First season: In the $1^{\text {st }}$ cut, germination recorded $38.33 \%$ for control. The soil amendment increased germination from $47.67 \%$ for composite $(\mathrm{C}, \mathrm{G}$ and $\mathrm{S})$ treatment to $61.67 \%$ for (Nano-particles) treatment, with an average mean of $52.52 \%$ across all studied treatments. Potassium silicate recorded the best performances of plant height $(146.67 \mathrm{~cm})$, stem diameter $(1.50 \mathrm{~cm})$, No. tillers (2.31) and leaf/ stem ratio $(64.50 \%)$, respectively. Compost treatments had the highest fresh and dry yield (11.44 and $\left.3.09 \mathrm{t} \mathrm{fed}^{-1}\right)$ followed by $\mathrm{k}$ silicate $(11.11$ and $\left.2.99 \mathrm{t} \mathrm{fed}^{-1}\right)$, whereas Control gave lowest fresh and dry yield over all treatments (9.85 and $2.66 \mathrm{t} \mathrm{fed}^{-1}$, respectively).

Egypt. J. Agron. 38, No.1 (2016) 
Control treatment with recorded the lowest sand of established plants $(74.67 \%)$ while the highest percentage $(93 \%)$ recorded with nano -particles in the $2^{\text {nd }}$ cut. Sulphur and compost treatments had the tallest plants (243.33 and $242.67 \mathrm{~cm}$ ) over all treatments, also $\mathrm{k}$ silicate performed the highest values of stem diameter and No. tillers plant ${ }^{-1}(1.17 \mathrm{~cm}$ and 8.40 , respectively). Nano particles, $\mathrm{k}$ silicate and sulphur demonstrated the higher fresh $(24.44,17.04$ and $\left.17.00 \mathrm{t} \mathrm{fed}^{-1}\right)$ and dry yield $\left(6.60,4.60\right.$ and $\left.4.59 \mathrm{t} \mathrm{fed}^{-1}\right)$ comparing with the other soil amendment. Nano -particles, $\mathrm{k}$ silicate and composite (C, G and S) performed the highest total yield for fresh $\left(29.84,27.96\right.$ and $\left.27.32 \mathrm{t} \mathrm{fed}^{-1}\right)$ and dry yield $\left(10.15,8.81\right.$ and $\left.8.97 \mathrm{t} \mathrm{fed}^{-1}\right)$. The increase in yield was mainly due to greater plant height plant ${ }^{-1}$, stem diameter plant ${ }^{-1}$, number of tillers plant ${ }^{-1}$ and leaf /stem ratio. These results confirm the findings of Bukhari (2009).

Second season: As shown in Table 4-a there were significant effects $(\mathrm{P}<$ 0.05 ) of soil amendment treatments of yield and yield components among $1^{\text {st }}, 2^{\text {nd }}$ cuts and total fresh and dry yield.

Data of the first cut showed that germination increased in all treated plants and control when compared with first season percentages. Nano-particles gave the highest germination $(65.33 \%)$. The tallest plants was noticed for compost $(158.33 \mathrm{~cm})$ while, control gave the shortest plants $(91.33 \mathrm{~cm})$. Compost and nano-particles treatments gave the highest stem diameter values (1.31 and 1.27, respectively) while, gypsum and control had the lowest values $(0.97$ and $0.73 \mathrm{~cm}$, respectively). Number of tillers ranged from (3.39) of control to (5.66) of composite (C, G and S) with mean average of (4.72). Nano- particles and $\mathrm{k}$ silicate recorded the highest percentage of leaf/stem ratio across all treatments (69.35 and 69.33\%). Compost application had significantly increased biomass yields of forage grasses compared to unfertilized control plots (Warman \& Termeer, 2005).

Sulphur, nano-particles, composite (C,G and S) and $\mathrm{k}$ silicate treatments performed the highest fresh yield $\left(22.97,21.34,22.32\right.$ and $\left.21.27 \mathrm{t} \mathrm{fed}^{-1}\right)$ and dry yield $\left(6.89,6.40,6.74\right.$ and $\left.6.38 \mathrm{t} \mathrm{fed}^{-1}\right)$, respectively. Standing after the first cut indicated higher establishment of plants under salt soil with an average of $(88.02 \%)$ across all treatments.

Second cut shows the tallest plants and largest stem diameter (234.67 and $1.50 \mathrm{~cm}$ ) of compost across all treatments. Nano-particles and sulphur treatments recorded the largest number of tillers plant ${ }^{-1}$ (18.56 and 17.00) and highest leaf stem ratio (67. 67\%). Higher fresh and dry yield for all treatments, was occurred in the second season comparing with first season. Hanafey \& Abd El-Rahman (2014) reported that a nano particle was significantly increased shoot biomass of wheat. These results were agreed with Kandil \& Gad (2010).

$\mathrm{K}$ silicate, nano-particles and sulphur showed the highest fresh yield (32.11, 30.67 and $30.33 \mathrm{t} \mathrm{fed}^{-1}$ ) and dry yield $\left(8.67,8.28\right.$ and $\left.8.19 \mathrm{t} \mathrm{fed}^{-1}\right) . \mathrm{K}$ silicate, sulphur and nano-particles also gave the highest total fresh $(53.38,53.30$ and $\left.52.01 \mathrm{t} \mathrm{fed}^{-1}\right)$ and dry yield $\left(15.05,15.08\right.$ and $\left.14.68 \mathrm{t} \mathrm{fed}^{-1}\right)$, respectively. Cakmak 
(2005) suggest that the improvement of K-nutritional status of plants might be of great importance for the survival of crop plants under environmental stress conditions, such as drought, chilling, and high light intensity. The superior yield for potassium silicate; may be due to the role of potassium in water regulation, intake and increase water use efficiency (Abou- Baker et al., 2011), in addition to the role of potassium in mitigating the toxic effect of $\mathrm{Na}$ (Abou-Baker et al., 2012). Nano practices $\mathrm{CaCO}_{3}$ fertilizer used for improving wheat productivity under salt-affected soil conditions via enhancement growth traits; increasing leaf pigments and membrane stability index (Hanafey \& Abd El- Rahman, 2014).

\section{Pearl millet growth attributes}

The effects of some soil amendments were significant differences $(\mathrm{P}<0.05)$ on yield and yield components of forage Pearl millet in the two successive seasons (Table 4-b).

First season: Germination among treatments recorded that nano- particles and gypsum were the highest percentages in the $1^{\text {st }}$ season $(53.67 \%$ and $53.33 \%)$ and $2^{\text {nd }}$ season $(71.67 \%$ and $66.67 \%)$, respectively (Table 4-b). Control treatment had the lowest values overall treatments across cuts and seasons. In the first cut $\mathrm{k}$ silicate treatment reported the highest plant height $(120.67 \mathrm{~cm})$, stem diameter $(0.73 \mathrm{~cm})$, number of tillers $(7.43)$ and $\mathrm{L} / \mathrm{S} \%(63.35 \%)$, respectively. Whereas, compost treatment gave the highest plant height $(140.0 \mathrm{~cm})$, stem diameter $(1.03 \mathrm{~cm})$ and number of tillers (13.73) in the second cut. The highest fresh and dry yielding recorded for nano particles and $\mathrm{k}$ silicate treatments in the $1^{\text {st }}$ cut $(13.67$, $4.86 \mathrm{t} \mathrm{fed}^{-1}$ and $13.02,4.37 \mathrm{t} \mathrm{fed}^{-1}$, respectively) and in the $2^{\text {nd }}$ cut $(16.17,5.29$ $\mathrm{t} \mathrm{fed}^{-1}$ and 16.32 and $5.15 \mathrm{t} \mathrm{fed}^{-1}$, respectively). In the second cut nano particles, $\mathrm{k}$ silicate and compost treatments recorded the highest stand of establishment in salt soils (80.0, 80.0 and 73.33\%). Compost, composite (C, G and S) and k silicate treatments performed the highest number of tillers (13.73, 13.67 and 12.80, respectively). The highest total fresh and dry yield recorded for Nano particles (29.84 and $\left.10.15 \mathrm{t} \mathrm{fed}^{-1}\right)$, k silicate (27.96 and $\left.8.81 \mathrm{t} \mathrm{fed}^{-1}\right)$ and composite $(\mathrm{C}, \mathrm{G}$

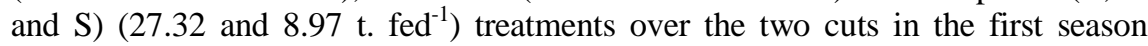
(Table 4-b). Sulphur fertilization can be increased yield and the quality of forages in the areas of sulphur deficient soils (Hallmark \& Brown, 1994).

Second season: In the $2^{\text {nd }}$ season there were significant effects $(\mathrm{P}<0.05)$ of soil amendment treatments over the two cuts on yield and yield components (Table 4-b).

Germination ranged from $26.67 \%$ for control to $71.67 \%$ for nano particles treatment. In the $1^{\text {st }}$ cut sulphur and compost treatments had the tallest plants $(124.75$ and $124.76 \mathrm{~cm})$, while in the $2^{\text {nd }}$ cut nano particles and compost treatments (153.33 and 152.33) showed the tallest plants. Compost and sulphur treatments recorded the highest number of tillers (7.53 and 7.23) in the $1^{\text {st }}$ cut, whereas both of $\mathrm{k}$ silicate and nano-particles treatments gave the highest number of tillers (12.67 and 12.36) in the $2^{\text {nd }}$ cut. Stand of establishing plants averaged 
from $62.00 \%$ for control to $88.0 \%$ for nano particles with average mean $78.41 \%$ over all treatments.

In the $1^{\text {st }}$ cut leaf stem ratio ranged from $37.00 \%$ of control to $69.33 \%$ for both $\mathrm{K}$ silicate and nano particles treatments. Whereas, nano particles, sulphur and gypsum had the highest leaf stem ratio $(62.67,60.67$ and $60.67 \%)$ in the $2^{\text {nd }}$ cut. Nano particles treatment performed the highest fresh and dry yield in the $1^{\text {st }}$ cut $\left(18.54,5.76 \mathrm{t} \mathrm{fed}^{-1}\right), 2^{\text {nd }}$ cut $\left(23.75,6.18 \mathrm{t} \mathrm{fed}^{-1}\right)$ and total yield across cuts $(42.29$ and $\left.11.94 \mathrm{t} \mathrm{fed}^{-1}\right)$, respectively.

\section{Macro and micro-nutrients concentrations in forage}

Data in Table $5(\mathrm{a}, \mathrm{b})$ show that in forage of $\mathrm{N}, \mathrm{P}$ and $\mathrm{K}$ contents. These contents were increased by all compost, sulphur and gypsum, composite $(C, G$ and S), Nano-particles, and Potassium silicate application, the compared to control. The lowest contents of these nutrients were observed for the control treatments. The $\mathrm{N}, \mathrm{P}$ and $\mathrm{K}$ concentration in pearl millet and sudan grass plants $(\%)$ in the two seasons were decreased with increasing soil salinity, The data of $\mathrm{N}, \mathrm{P}$ and $\mathrm{K}$ content in Pearl millet and Sudan grass plants show relative increase with decrease of soil salinity as a result of adding different amendments. In $1^{\text {st }}$ season $\mathrm{N}$ contents in Sudan grass plant tissues ranged from 0.87 to $1.72 \%$ in the $1^{\text {st }}$ cut and from 1.38 to $2.23 \%$ in the $2^{\text {nd }}$ cut. While in the $2^{\text {nd }}$ season $\mathrm{N}$ contents in plant tissues ranged from 1.07 to $1.86 \%$ in the $1^{\text {st }}$ cut and from 1.39 to $2.150 \%$, in the $2^{\text {nd }}$ cut. $\mathrm{P}$ contents ranged from 0.76 to $0.93 \%$ in the $1^{\text {st }}$ season and from 0.79 to $0.84 \%$ in the $2^{\text {nd }}$ season. $\mathrm{K}$ contents ranged from 2.13 to 2.43 $\%$ in the $1^{\text {st }}$ season and from 2.24 to $3.45 \%$ in the $2^{\text {nd }}$ season, respectively. The relative increases of the contents of $\mathrm{N}, \mathrm{P}$ and $\mathrm{K}$ in the plant tissues of Sudan grass are mainly depend on the type of treatments used. Compost and composite $(\mathrm{C}, \mathrm{G}$ and $\mathrm{S}$ ) gave the highest content of $\mathrm{N} \%$ in plant tissues over the two cuts and seasons. In the $1^{\text {st }}$ season $\mathrm{P}$ performed higher contents of compost $(0.94 \%)$ and composite (C, G and S) $(0.84 \%)$ of the $1^{\text {st }}$ cut and for compost $(90.99 \%)$ and nano-particles $(0.98 \%)$ of the $2^{\text {nd }}$ cut, respectively. In the $2^{\text {nd }}$ season compost and $\mathrm{K}$ silicate treatments $(0.93$ and $0.84 \%)$ of the $1^{\text {st }}$ cut, while $\mathrm{K}$ silicate and nanoparticles treatments $(0.98$ and $0.96 \%)$ of the $2^{\text {nd }}$ cut recorded the highest $\mathrm{P}$ contents. $K$ content recorded an average of ( 2.13 and 2.43 ) for the $1^{\text {st }}$ and $2^{\text {nd }}$ cuts in the $1^{\text {st }}$ season and (2.24) over cuts in the $2^{\text {nd }}$ season. This finding is in agreement with results obtained by Kandil \& Gad (2010). They reported that the nutrient ( $\mathrm{N}, \mathrm{P}$ and $\mathrm{K}$ ) uptake by tomato, onion and sunflower were strikingly increased by the application of sulphur compared to gypsum.

On the other hand, the effects of using soil amendments and simulating plant growth applications under saline soil on the concentrations of $\mathrm{Mn}, \mathrm{Zn}, \mathrm{Fe}$ and $\mathrm{Cu}$ in Sudan grass and Pearl millet plants were presented in Table 5 (a,b). Sulphur application at rates of (1) $\mathrm{mg} \mathrm{fed}^{-1}$ to saline soil was associated with changes of $\mathrm{Mn}, \mathrm{Zn}, \mathrm{Fe}$ and $\mathrm{Cu}$ accumulation in the plant tissues of Sudan grass and Pearl millet plants. The corresponding mean values of $\mathrm{Mn}\left(23.22,38.56 \mathrm{mgKg}^{-1}\right), \mathrm{Zn}$ $\left(6.76,7.92 \mathrm{mgKg}^{-1}\right), \mathrm{Fe}\left(319.13,526.8 \mathrm{mgKg}^{-1}\right)$ and $\mathrm{Cu}\left(3.84,5.91 \mathrm{mgKg}^{-1}\right)$ per each cut in the $1^{\text {st }}$ season also, Mn $\left(34.88,32.75 \mathrm{mgKg}^{-1}\right), \mathrm{Zn}\left(7.17,7.40 \mathrm{mgKg}^{-1}\right)$, 
Fe (and 526.8, $\left.370.27 \mathrm{mgKg}^{-1}\right) \mathrm{Cu}$ and $\left(5.42,4.25 \mathrm{mgKg}^{-1}\right)$ in the $2^{\text {nd }}$ season, respectively. While, the corresponding mean values of $\mathrm{Mn}, \mathrm{Zn}, \mathrm{Fe}$ and $\mathrm{Cu}$ accumulation in Pearl millet plants per each cut were $\left(39.53,48.18 \mathrm{mgKg}^{-1}\right)$ of $\mathrm{Mn}$, $\left(6.61,7.60 \mathrm{mgKg}^{-1}\right)$ of $\mathrm{Zn},\left(421.29,450.92 \mathrm{mgKg}^{-1}\right)$ of $\mathrm{Fe}$ and $\left(4.49,4.35 \mathrm{mgKg}^{-1}\right)$ of $\mathrm{Cu}$ contents in the $1^{\text {st }}$ season. In The $2^{\text {nd }}$ season the micronutrients were accumulated $\left(28.30,32.61 \mathrm{mgKg}^{-1}\right)$ of $\mathrm{Mn},\left(7.20,8.35 \mathrm{mgKg}^{-1}\right)$ of $\mathrm{Zn},(624.80$, $\left.657.10 \mathrm{mgKg}^{-1}\right)$ of $\mathrm{Fe}$ and $\left(6.74,6.53 \mathrm{mgKg}^{-1}\right)$ of $\mathrm{Cu}$ per each cut, respectively. This finding is in agreement with results obtained by Carter \& Cutcliffe (1990). They found that gypsum had little effect on soil porosity and structure indices, but it has a role in changing soil $\mathrm{pH}$ and significantly influenced soil microbial biomass. El-Rashidi et al. (2010) found that the application of peat improved the solubility of most nutrients and proved to be useful as an amendment for gypsumrich soils and increases its productivity. These results are in agreement with the results obtained by Kandil, \& Gad (2010).

TABLE 5a. Sudan grass content of macro- and micronutrients as affected by the studied treatments.

\begin{tabular}{|c|c|c|c|c|c|c|c|c|c|c|c|c|c|c|}
\hline \multirow{2}{*}{ Treatments } & \multicolumn{6}{|c|}{ Macronutrients (\%) } & \multicolumn{8}{|c|}{ Micronutrients $\left(\mathrm{mgkg}^{-1}\right)$} \\
\hline & \multicolumn{2}{|c|}{$\mathbf{N}$} & \multicolumn{2}{|c|}{$\mathbf{P}$} & \multicolumn{2}{|c|}{$\mathbf{K}$} & \multicolumn{2}{|c|}{ Mn } & \multicolumn{2}{|c|}{$\mathbf{Z n}$} & \multicolumn{2}{|c|}{$\mathrm{Fe}$} & \multicolumn{2}{|c|}{$\mathbf{C u}$} \\
\hline \multicolumn{15}{|c|}{ First cut } \\
\hline Seasons & $1^{\text {st }}$ & $2^{\text {nd }}$ & $1^{\text {st }}$ & $2^{\text {nd }}$ & $1^{\text {st }}$ & $2^{\text {nd }}$ & $1^{\text {st }}$ & $2^{\text {nd }}$ & $1^{\mathrm{st}}$ & $2^{\text {nd }}$ & $1^{\text {st }}$ & $2^{\text {nd }}$ & $1^{\text {st }}$ & $2^{\text {nd }}$ \\
\hline Control & 0.870 & 1.070 & 0.58 & 0.64 & 0.31 & 0.43 & 2.45 & 33.00 & 2.75 & 3.40 & 174.25 & 217.80 & 2.10 & 2.70 \\
\hline Sulphur & 1.460 & 1.650 & 0.73 & 0.76 & 1.86 & 1.95 & 11.10 & 23.50 & 8.05 & 5.75 & 245.60 & 357.40 & 2.80 & 3.45 \\
\hline Gypsum & 1.630 & 1.625 & 0.74 & 0.77 & 2.57 & 2.61 & 30.45 & 28.95 & 5.30 & 8.40 & 222.90 & 442.80 & 2.35 & 3.75 \\
\hline Compost & 1.720 & 1.865 & 0.94 & 0.93 & 2.92 & 2.97 & 30.70 & 24.65 & 7.20 & 7.77 & 253.85 & 581.40 & 3.15 & 4.75 \\
\hline $\mathrm{C}+\mathrm{G}+\mathrm{S}$ & 1.710 & 1.825 & 0.84 & 0.78 & 2.27 & 2.36 & 30.90 & 53.90 & 8.40 & 8.77 & 405.00 & 667.00 & 4.30 & 6.65 \\
\hline $\mathrm{K}$ silicate & 1.460 & 1.645 & 0.77 & 0.84 & 3.03 & 3.33 & 27.40 & 43.15 & 8.30 & 8.43 & 451.70 & 672.80 & 4.90 & 7.20 \\
\hline Nano particles & 1.440 & 1.520 & 0.73 & 0.79 & 1.92 & 2.05 & 29.55 & 37.00 & 7.30 & 7.69 & 480.60 & 748.25 & 7.30 & 9.45 \\
\hline Mean & 1.583 & 1.600 & 0.76 & 0.79 & 2.13 & 2.24 & 23.22 & 34.88 & 6.76 & 7.17 & 319.13 & 526.8 & 3.84 & 5.42 \\
\hline Significance & $* *$ & $* *$ & $* *$ & $* *$ & $* *$ & $* *$ & $* *$ & $* *$ & $* *$ & $* *$ & $* *$ & $* *$ & $* *$ & $* *$ \\
\hline \multicolumn{15}{|c|}{ Second cut } \\
\hline Control & 1.380 & 1.390 & 0.81 & 0.66 & 0.53 & 0.42 & 34.45 & 3.25 & 4.25 & 3.3 & 255.15 & 300.4 & 2.80 & 2.7 \\
\hline Sulphur & 1.670 & 1.890 & 0.91 & 0.77 & 1.98 & 1.96 & 30.90 & 16.6 & 6.60 & 8.95 & 363.60 & 246.65 & 3.75 & 2.7 \\
\hline Gypsum & 1.740 & 1.850 & 0.97 & 0.81 & 2.75 & 2.63 & 33.00 & 31.55 & 9.25 & 5.55 & 464.20 & 288.65 & 4.03 & 2.8 \\
\hline Compost & 2.230 & 2.150 & 0.99 & 0.84 & 3.30 & 3.02 & 27.15 & 36.1 & 8.50 & 8.3 & 582.25 & 356.8 & 4.95 & 3.8 \\
\hline $\mathrm{C}+\mathrm{G}+\mathrm{S}$ & 1.965 & 1.970 & 0.93 & 0.85 & 2.47 & 2.32 & \begin{tabular}{|l|}
55.35 \\
\end{tabular} & 37.25 & 9.30 & 9.35 & 652.05 & 443.15 & 7.20 & 4.7 \\
\hline K Silicate & 1.875 & 1.770 & 0.94 & 0.98 & 3.82 & 3.45 & 47.85 & 36.2 & 8.80 & 8.6 & 699.05 & 459.15 & 8.85 & 5.5 \\
\hline Nano particles & 1.650 & 1.740 & 0.98 & 0.96 & 2.15 & 1.92 & 41.20 & 32.75 & 8.73 & 7.75 & 876.35 & 497.1 & 9.80 & 7.55 \\
\hline Mean & 1.930 & 1.823 & 0.93 & 0.84 & 2.43 & 2.24 & 38.56 & \begin{tabular}{|l|} 
\\
\end{tabular} & 7.92 & 7.4 & 556.09 & 370.27 & 5.91 & 4.25 \\
\hline Significance & ** & ** & ** & ** & ** & ** & $* *$ & ** & ** & $* *$ & $* *$ & ** & $* *$ & $* *$ \\
\hline
\end{tabular}

Egypt. J. Agron . 38, No.1 (2016) 
ENVIRONMENTAL MANAGEMENT OF SALT AFFECTED SOILS ...

TABLE 5b. Pearl millet content of macro- and micronutrients as affected by the studied treatments.

\begin{tabular}{|c|c|c|c|c|c|c|c|c|c|c|c|c|c|c|}
\hline \multirow{2}{*}{ Treatments } & \multicolumn{6}{|c|}{ Macronutrients (\%) } & \multicolumn{8}{|c|}{ Micronutrients (mgkg ${ }^{-1}$ ) } \\
\hline & \multicolumn{2}{|c|}{$\mathbf{N}$} & \multicolumn{2}{|c|}{$\mathbf{P}$} & \multicolumn{2}{|c|}{$\mathbf{K}$} & \multicolumn{2}{|c|}{ Mn } & \multicolumn{2}{|c|}{$\mathbf{Z n}$} & \multicolumn{2}{|c|}{$\mathbf{F e}$} & \multicolumn{2}{|c|}{$\mathrm{Cu}$} \\
\hline \multicolumn{15}{|c|}{ First cut } \\
\hline Seasons & $1^{\mathrm{st}}$ & $2^{\text {nd }}$ & $1^{\mathrm{st}}$ & $2^{\text {nd }}$ & $1^{\mathrm{st}}$ & $2^{\text {nd }}$ & $1^{\text {st }}$ & $2^{\text {nd }}$ & $1^{\mathrm{st}}$ & $2^{\text {nd }}$ & $1^{\mathrm{st}}$ & $2^{\text {nd }}$ & $1^{\mathrm{st}}$ & $2^{\text {nd }}$ \\
\hline Control & 0.793 & 0.97 & 0.61 & 0.61 & 1.82 & 1.85 & 2.23 & 3.53 & 3.31 & 5.50 & 170.95 & 256.42 & 3.20 & 4.80 \\
\hline Sulphur & 1.24 & 1.38 & 0.82 & 0.94 & 2.63 & 2.85 & 24.15 & 31.95 & 6.7 & 6.70 & 249.65 & 374.48 & 3.70 & 5.55 \\
\hline Gypsum & 1.245 & 1.36 & 0.99 & 0.82 & 2.06 & 3.44 & 45.50 & 25.95 & 5.95 & 8.40 & 318.95 & 478.42 & 3.50 & 5.25 \\
\hline Compost & 1.546 & 1.87 & 0.94 & 0.61 & 2.94 & 3.87 & 42.70 & 33.85 & 7.95 & 8.45 & 390.6 & 585.90 & 4.05 & 6.07 \\
\hline $\mathrm{C}+\mathrm{G}+\mathrm{S}$ & 1.551 & 1.84 & 0.81 & 0.76 & 3.61 & 3.55 & 62.15 & 36.65 & 7.00 & 7.45 & 469.55 & 704.33 & 4.65 & 6.97 \\
\hline $\mathrm{K}$ silicate & 1.31 & 1.56 & 0.94 & 0.54 & 3.42 & 4.68 & 33.55 & 39.55 & 6.80 & 5.20 & 652.25 & 978.38 & 5.50 & 8.25 \\
\hline Nano particles & 1.27 & 1.55 & 0.69 & 0.80 & 3.93 & 3.13 & 66.45 & 26.60 & 8.60 & 8.70 & 697.1 & 995.65 & 6.85 & 10.27 \\
\hline Mean & 1.279 & 1.504 & 0.83 & 0.73 & 2.92 & 3.34 & 39.53 & 28.30 & 6.61 & 7.20 & 421.29 & 624.80 & 4.49 & 6.74 \\
\hline Significance & $* *$ & $* *$ & $* *$ & $* *$ & $* *$ & $* *$ & $* *$ & $* *$ & $* *$ & $* *$ & $* *$ & $* *$ & $* *$ & $* *$ \\
\hline \multicolumn{15}{|c|}{ Second cut } \\
\hline Control & 1.06 & 1.39 & 0.66 & 0.62 & 1.86 & 1.88 & 2.63 & 5.05 & 3.87 & 6.40 & 183.75 & 275.63 & 3.40 & 5.10 \\
\hline Sulphur & 1.43 & 1.58 & 0.97 & 0.99 & 2.54 & 2.53 & 34.35 & 34.10 & 7.50 & 7.85 & 265.60 & 398.40 & 3.65 & 5.47 \\
\hline Gypsum & 1.465 & 1.70 & 0.61 & 0.86 & 2.43 & 3.75 & 55.00 & 31.05 & 6.85 & 9.50 & 336.35 & 504.52 & 3.40 & 5.10 \\
\hline Compost & 1.59 & 2.05 & 0.96 & 0.71 & 3.18 & 3.86 & 55.45 & 42.25 & 8.75 & 9.10 & 444.10 & 666.15 & 4.25 & 6.38 \\
\hline $\mathrm{C}+\mathrm{G}+\mathrm{S}$ & 1.58 & 1.97 & 0.88 & 0.87 & 3.00 & 3.67 & 72.35 & 36.70 & 8.55 & 9.60 & 525.60 & 788.40 & 4.80 & 7.20 \\
\hline $\mathrm{K}$ silicate & 1.64 & 1.84 & 0.97 & 0.61 & 2.79 & 4.91 & 45.75 & 43.10 & 8.65 & 6.75 & 654.00 & 981.00 & 5.15 & 7.72 \\
\hline Nano particles & 1.534 & 1.72 & 0.63 & 0.89 & 3.66 & 3.72 & 71.75 & 36.05 & 9.05 & 9.25 & 747.05 & 985.58 & 5.80 & 8.70 \\
\hline Mean & 1.471 & 1.750 & 0.81 & 0.79 & 2.78 & 3.47 & 48.18 & 32.61 & 7.60 & 8.35 & 450.92 & 657.10 & 4.35 & 6.53 \\
\hline Significance & $* *$ & $* *$ & $* *$ & *** & $* *$ & *** & $* *$ & $* *$ & $* *$ & $* *$ & $* *$ & $* *$ & ** & $* *$ \\
\hline
\end{tabular}

From the obtained results, it could be concluded that the application of tested soil amendments (compost, sulphur and gypsum, composite (C, G and S) and simulating plant growth applications (nano-particles and $\mathrm{K}$ silicate) under saline soil condition. Using of soil amendments under salt affected soils led to increase the soil content of available macro- and micronutrients contents, increase soil fertility and positively reflected on forage yield and yield components. Thus it could be recommended that using of the compost at a rate $5 \mathrm{Mg} \mathrm{fed}^{-1}$ gave an economic crop and get on the fertility of the soil suitable for the production of a good forage yield.

\section{Conclusion}

Saline sandy clay soils which are poor in physical and chemical properties as well as low in fertility can be used for pasture in the North Sinai, if managed correctly. Soils of Sahl El-Tina in North Sinai require to high-quality management to produce high yielding under its specialized conditions. Adding of soil amendments and simulating plant growth to alleviate the negative effects of salinity conditions and improve plant adaptation to salt soils and increase plant 
efficiency to improve yield and quality of Sudan grass and Pearl millet forage crops. Also, reduce the high cost of buying consumed fodder and maintaining the long term productivity of soils for sustainable agriculture.

\section{References}

Abdel Aal, S.I., Hamid, A.M.A., Ismaiel, S.A., Abd El-Fattah, A. and Taalab, A.S. (2003) Effect of organic farming practice on nutrition, availability and wheat yield grown on torripsamments. Egypt. J. Soil Sci. 43(1), 47-62.

Abou-Baker, N.H., Abd-Eladl, M. and Abbas, M.M. (2011) Use of silicate and different cultivation practices in alleviating salt stress effect on bean plants. Australian Journal of Basic and Applied Sciences, 5(9), 769-781.

Abou-Baker, N.H., Abd-Eladl, M. M. and Eid, T.A. (2012) Silicon and water regime responses in bean production under soil saline condition. Journal of Applied Sciences Research, 8(12) 5698-5707.

Adekunle, A. A. (2012) Agricultural innovation in Sub-Saharan Africa: experiences from multiplestakeholder approaches. Forum for Agricultural Research in Africa, Ghana. ISBN 978-9988-8373-2-4.

Amezketa, E., Aragues, R. and Gazol, R. (2005) Efficiency of sulfuric acid, mined gypsum and two gypsum by-products in soil crusting prevention and sodic soil reclamation. Agron. J. 97, 983-989.

Bilal, B.A. (2010) Lithovit: An innovative fertilizer. The $3^{\text {rd }}$ e- Conference on Agricultural Biosciences (IeCAB 2010), $1^{\text {st }}-15^{\text {th }}$ June 2010. http://www.slideserve. com/madison/ lithovit- an-innovative- fertilizer. Accessed 10 April 2014.

Black, C.A. (Ed) (1965) "Methods of Soil Analysis". Ser. Agron. No 9 Amer. Soc. Agron., Madison, Wisconsin. Studies on growth characteristics and dry matter accumulation of pearl millet and sorghum hybrids. Research Report of Rural Development Administration, Livestock. 32, pp.45-53.

Brunner, P.H. and Wasmer, H. R. (1978) Methods of analysis of sewage sludge solid wastes and compost . W.H.O. International Reference Center for Wastes Disposal (H8600), Dulendrof Switzerland.

Bukhari , M.A. (2009) Effect of different harvesting intervals on growth, forage yield and quality of pearl millet (Pennisetum americanum L.) cultivars. M.sc., Thesis, University of Agriculture, Faisalabad, Pakistan.

Cakmak, I. (2005) The role of potassium in alleviating detrimental effects of abiotic stresses in plants. J. Plant Nutr. Soil Sci., 168.

Carter, M.R. and Cutcliffe, J.A. (1990) Effects of gypsum on growth and mineral content of brussels sprouts, and soil properties of Orthic Podzols. Fertilizer Research, 24, 77- 84 . 
Choi, B.H., Park, K.Y. and Park, R.K. (1993) Pearl millet hybrid of high quality and yield: A new green fodder crop in Korea. Pages 485-497. In: Crop Production and Improvement Technology in Asia. Proc. of the First Asian Crop Science Conf. Sept. 1992, Seoul, Korea. pp. 24-28.

Courtney, R. G. and Mullen, G. J. (2008) Soil quality and barley growth as influenced by the land application of two compost types.Bioresource Technology, 99, 29132918.

El-Rashidi, M. A., West, L.T., Seybold, C.A., Benham, E.C., Schoeneberger, P. J. and Ferguson, R. (2010) Effects of gypsum addition on solubility of nutrients in soil amended with peat. Soil Sci. 175 (4), 162- 172.

Elyas, S.H.A., El Tinay, A.H., Yousif , N.E. and Elsheikh, E.A.E. (2002) Effect of natural fermentation on nutritive value and in vitro protein digestibility of pearl millet Food Chemistry, 78, 75-79.

Ghoulam, C., Foursy, A. and Fares, K. (2002) Effects of salt stress on growth, inorganic ions and proline accumulation in relation to osmotic adjustment in five sugar beet cultivars. Environ.Exp. Bot. 47, 9-50.

Hallmark, W.B. and Brown, L.P. (1994) Interactive effects of sulphur and potassium fertilization on Bermudagrass hay yields. Sulphur Agric. 18, 41-44.

Hamza, M. A. and Anderson, W. K. (2003) Responses of soil properties and grain yields to deep ripping and gypsum application in a compacted loamy sand soil contrasted with a sandy clay loam soil in Western Australia. Australian Journal of Agricultural Research, 54, 273-282.

Hanafey, Maswada F. and Abd El-Rahman, Lamyaa A. (2014) Inducing salinity tolerance in wheat plants by hydrogen peroxide and lithovit "a nano- $\mathrm{CaCo}_{3}$ fertilizer J. Agric. Res. Kafr El-Sheikh Univ. 40 (4), 696-719.

Hussain, N., Hassan, G., Arshadullah, M. and Mujeeb, F. (2001) Evaluation of amendments for the improvement of physical properties of sodic soil. Int. J. Agri Biol. 3 (3),319.

Kaiser, M.F. (2009) Environmental changes remote sensing, and infrastructure development: The case of Egypt's East Port Said harbour. J. Applied Geography, 29, 280- 288 .

Khan, R., Gurmani, A., Sohail, M. and Hussain, A. (2006) Effect of gypsum application on rice yield under Wheat \& Rice System. Int. J. Agric. Biol. 8 (4), 536538 .

Kandil, H. and Gad, N. (2010) Response of tomato plants to sulphur and organic fertilizer . Int .J. of Acad Res. 2 (3), 204 -210.

Lai, J.K., Mishra, B. and Sarkar, A. K. (2000) Effect of sulphur on availability of some plant nutrients. Indian J. Society of Soil Science, 48(1), 67-71. 
Mahmoud, Awatef A. (2011) Impact of some sulphur sources on ameliorating soil characteristics, wheat yield and grain quality under newly reclaimed saline soil conditions Fayoum, J. Agric. Res. \& Dev. 25 (1), 36 - 48.

Miron, J., Zuckerman, E., Adin, G., Shoshani, R., Nikbachat, M., Yosef, E., Zenou, A., Weinberg, A.G., Chen, Y., Halachmi, I. and Ben-Ghedalia, D. (2007) Comparison of two forage sorghum varieties with corn and the effect of feeding their silage on eating behavior and lactation performance of dairy cows. Anim. Feed Sci. Tech. 139, 23-39.

Olanite, J. A., Anele, U. Y., Arigbede, O. M., Jolaosho, A. O. and Onifade, O. S. (2010) Effect of plant spacing and nitrogen fertilizer levels on the growth, dry-matter yield and nutritive quality of Columbus grass (Sorghum almum stapf) in southwest Nigeria. Grass Forage Sci. 65(4), 369375.

Page, A.L, Miller, R.H. and Keeney, D.R. (1982) "Methods of Chemical Analysis". Part 2: "Chemical and Microbiological Properties" (Second Edition). American Society of Agronomy, Inc. and Sci., Soc. of America, Inc. Publishers, Madison, Wisconsin U.S.A.

Rai, K.N., Reddy, B.V.S., Saxena, K.B. and Gowda, C.L.L. (2004) Prospects of breeding sorghum, pearl millet and pigeonpea for high forage yield and quality. http://www.cropscience.org.au/icsc2004/poster/5/2/1033_raikn.htm.

Rebecca, B. (2004) Soil survey laboratory methods manual. Soil Survey Investigations Report No. 42, Natural Resources Conservation Services.

Saberi, A. (2013) Biochemical composition of forage sorghum (Sorghum bicolor L.) varieties under influenced of salinity and irrigation frequency. Int. J. Traditional and Herbal Med. 1 (2), 28-37.

SAS (2004) SAS Statistics User's Guide. Release 9.2. SAS Institute, Cary, NC. USA.

Serrano, R., Macia, F.C. and Moreno, V. (1999) Genetic engineering of salt and drought tolerance with yeast regulatory genes, Sci. Hortic.78, 261-269.

Shannon, M.C. (1998) Adaptation of plant to salinity, Adv.Agron. 60, 75- 119.

Singh, B.R. and Singh, D.P. (1995) Agronomic and physiological response of sorghum, maize and pearl millet to irrigations. Field Crops Research, 42, 57-67.

Soltanpour , N. (1985) Use of ammonium bicarbonate- DTPA soil test to evaluate element availability and toxicity. Soil Sci. Plant Anal. 16 (3), 323 - 338.

Vance, W. H., Tisdell, J. M. and McKenzie, B. M. (1998) Residual effects of surface application of organic matter and calcium salts on the subsoil of a red brown earth. Australian Journal of Experimental Agriculture, 38, 595-600.

Vyas, A.K. and Rai, R.K. (1985) Responses of maize, sorghum and pearl millet as forage to varying levels of phosphorus. Indian Journal of Agronomy, 30, 527-528.

Warman, P.R. and Termeer, W.C. (2005) Evaluation of sewage sludge, septic waste, and sludge compost applications to corn and forage; yields and N, P and K content of

Egypt. J. Agron . 38, No.1 (2016) 
crops and soils. Bioresource Technol. 96, 955-961. DOI: 10.1016 / j. biortech. 2004. 08.003.

Wong, V. N. L., Dalal, R. C. and Greene, R. S. B. (2009) Carbon dynamics of sodic and saline soils following gypsum and organic material additions: a laboratory incubation. Applied Soil Ecology, 41, 29-40.

Yan, K., Chen, P., Shao, H., Zhao, S., Zhang, L. , Xu, G. and Sun, J. (2012) Responses of photosynthesis and photosystem II to higher temperature and salt stress in Sorghum. J. Agron. and Crop Sci. 198(3), 218-225.

Yang, X., Wan, Z., Perry, L., Lu, H., Wang, Q., Hao, C., Li, J., Xie, F. , Yu, J., Cui, T., Wang, T. , Li , M. and Ge, Q. H. (2012) Early millet use in northern China. Proc. Nat. Acad. Sci. USA pp.1-5.

(Received $11 / 1 / 2016$ accepted 18 /4 / 2016) 


\title{
إدارة الأراضى المتأثرة بالأملاح وتأثيرها على محصول وجودة \\ الأعلاف في شُمال سيناء الارأرة
}

\author{
زينب محمد عبد النبي ، وفاء عبد الكريم حافظ"، سيد التهامي "ونبيلة علي محمد الكما

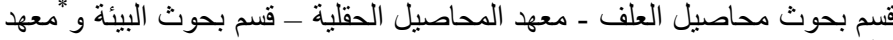

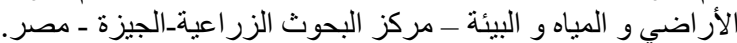

أجريت تجربتين حقليتين في قرية جلبانة بمنطقة سهل الطينة التابعة لمحافظة

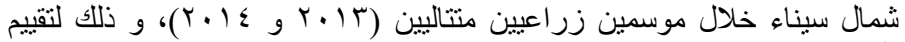

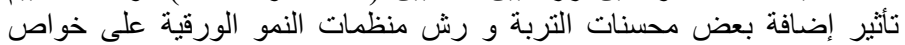

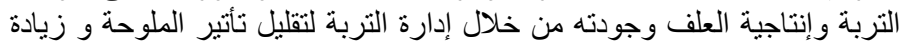

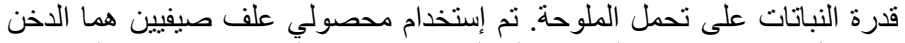
(شندويل- () و حشيشة السودان المحلية، وقد نفذت التهات التجارب بتصميم القطاعات

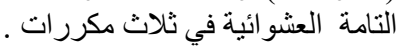

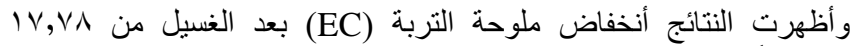

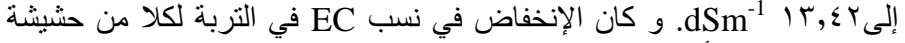

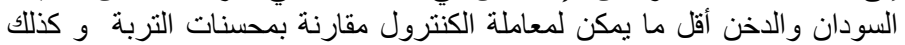

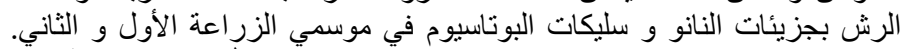

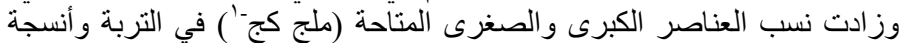

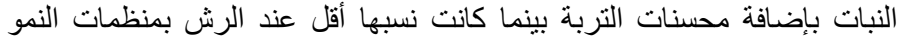

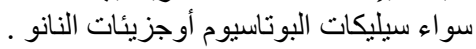

أظهرت كلا من حشيشة السودان و الدخن فروقا معنوية (PS

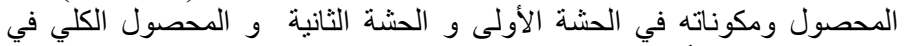
الموسم الزر اعي الأول و كذئل في في الموسم الثانى .

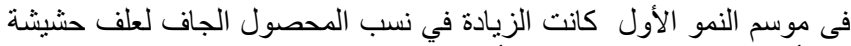

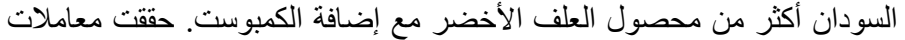

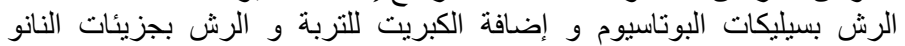

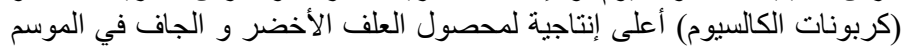
الزراعي الثانى . (كربوات الكيوم

حقق علف الاخن زيادة في محصول العلف الكلي الأخضر و الجاف مع رش وش البان

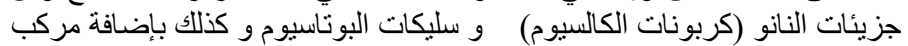

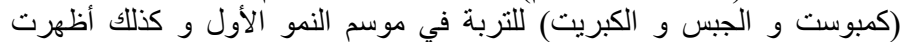

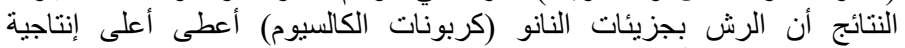
للمحصول العلفي الأخضر و الجاف في موسم النمو الثانى .

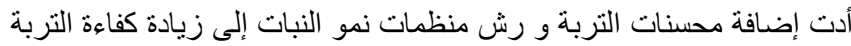

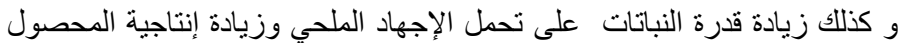

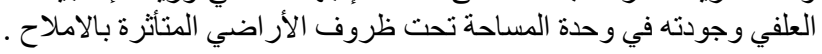

